JGRADASI TEKnIK SIPIL 


\section{JURNAL GRADASI TEKNIK SIPIL POLITEKNIK NEGERI BANJARMASIN}

Jurnal Gradasi Teknik Sipil diterbitkan oleh Pusat Penelitian dan Pengabdian Kepada Masyarakat Politeknik Negeri Banjarmasin. Ruang lingkup makalah meliputi Bidang Teknik dan Manajemen dengan konsentrasi Bidang Transportasi, Geoteknik, Struktur, Keairan dan Manajemen Konstruksi. Isi makalah dapat berupa penyajian isu aktual di bidang Teknik Sipil, review terhadap perkembangan penelitian, pemaparan hasil penelitian, dan pengembangan metode, aplikasi, dan prosedur di bidang Teknik Sipil. Makalah ditulis mengikuti panduan penulisan.

\section{Penanggung Jawab}

Nurmahaludin, ST, MT.

\section{Dewan Redaksi}

Ketua :

Anggota : Riska Hawinuti, ST, MT.

Nurfitriah, S.Pd, MA.

Ir. Rusliansyah, M.Sc.

\section{Reviewer}

Dr. Ir. Yanuar Jarwadi Purwanto, MS. (Institut Pertanian Bogor)

Dr. Ir. Achmad Rusdiansyah, MT. (Universitas Lambung Mangkurat)

Dr. Ir. M. Azhar, M. Sc. (Institut Sains dan Teknologi Nasional)

Dr. Ir. Endang Widjajanti, MT. (Institut Sains dan Teknologi Nasional)

Joni Irawan, ST, MT. (Politeknik Negeri Banjarmasin)

Yusti Yudiawati, ST, MT. (Politeknik Negeri Banjarmasin)

\section{Editing dan Tata Bahasa}

Nurfitriah, S.Pd., MA.

\section{Desain dan Tata Letak}

Abdul Hafizh Ihsani

\section{Alamat Redaksi}

Jurusan Gradasi Teknik Sipil Politeknik Negeri Banjarmasin, Jl. Brigjen H. Hasan Basri 70123 Banjarmasin Telp/Fax 0511-3307757; Email: gradasi.tekniksipil@poliban.ac.id 


\section{JURNAL GRADASI TEKNIK SIPIL}

\section{DAFTAR ISI}

Perencanaan Campuran Lapis Aspal Beton Permukaan Dengan Asbuton Butir Sebagai Filler ...( 1 - 9 )

Surat, Rifanie Gazalie, Pazilatul Mumamiroh

Pengaruh Keberadaan Pasar Sungai Lulut Terhadap Kinerja Jalan Martapura Lama KM. 05 ...( 10 - 19)

\section{Riska Hawinuti}

Analisis Perbandingan Biaya Penggunaan Perancah Kayu Galam Dan Perancah Besi (Scaffolding) ...( $20-32)$ Aunur Rafik, Rinova Firman Cahyani

Tinjauan Debit Andalan untuk Irigasi di Kecamatan Sungai Tabuk Kabupaten Banjar ...( $33-43)$

Fakhrurrazi, Herliyani Farial Agoes, Desi Anggeriyani

Ekosemen Sebagai Media Perekat Pengganti Semen Untuk Beton ...( 44 - 51 ) Marhadi Sastra, Juli Ardita Pribadi R

Pengaruh Posisi, Jumlah Layer Dan Mutu Kayu Terhadap Balok Laminasi Kayu Mahang Dan Kayu Meranti ...( 52 - 60 )

\section{Indriyani Puluhulawa}

Visualisasi Dan Identifikasi Pola Retak Dinding Bata Akibat Penurunan Pondasi Struktur Bangunan Di Kota Banjarmasin ...( 61 - 68 )

\section{Darmansyah Tjitradi, Eliatun}

Pengembangan Perumahan Dengan Desain Konstruksi Dilahan Basah Pada Wilayah Kota Banjarmasin Menggunakan Riset Operasi ...( 69 - 75 )

\section{Eliatun, Darmansyah Tjitradi}




\title{
Perencanaan Campuran Lapis Aspal Beton Permukaan Dengan Asbuton Butir Sebagai Filler
}

\author{
Surat $^{1}$, Rifanie Gazalie ${ }^{2}$, Pazilatul Mumamiroh ${ }^{3 *}$ \\ ${ }^{1,2}$ Dosen Jurusan Teknik Sipil Politeknik Negeri Banjarmasin \\ ${ }^{3}$ Mahasiswa Teknik Sipil \\ e-mail: ${ }^{1}$ surat@poliban.ac.id, ${ }^{2}$ rifanieg@gmail.com (correspondingauthor), ${ }^{3}$ fazilatulmumamiroh@yahoo.co.id
}

\begin{abstract}
Abstrak
Penelitian ini bertujuan memanfatkan mineral pada asbuton sebagai filler dan aspal akan diperhitungkan untuk mengurangi penggunaan aspal minyak dalam campuran Lapis Aspal Beton Permukaan. Material yang digunakan pada penelitian ini adalah agregat batu pecah dari Gunung Katunun, Kabupaten Tanah Laut, Kalimantan Selatan, aspal Pen 60/70 produksi Shell dan Asbuton butir 15/20. Penggunaan Asbuton dalam campuran Laston Permukaan sebesar 7\% dengan kadar aspal optimum 5,25\% didapat sifat-sifat campuran VIM 3,5\%, VMA 15,7\%, VFB 77,9\%, Stabilitas 1484kg, Kelelehan plastis 3,3 mm, VIM PRD 3,0\%, Stabilitas sisa 90,8\%. Pada kadar aspal optimum sebesar 5,25\% dilakukan percobaan campuran dengan penambahan Asbuton butir bervariasi 5,0\%, 9,0\%, 11,0\%, 13,0\% dari hasil pengujian Marshall menunjukan bahwa semakin besar penambahan Asbuton maka semakin tinggi nilai stabilitasnya, nilai stabilitas berurutan sebesar $1058 \mathrm{~kg}, 1449 \mathrm{~kg}$, $1509 \mathrm{~kg}, 1600 \mathrm{~kg}$. Kelelehan plastis dengan rentang 3,1 mm sampai dengan 3,5 mm, VIM 3,5\% sapai dengan 5,6\%,VMA 15,7\% sampai dengan 17,7\%, VFB 68,1\% sampai dengan 71,9\%. Hasil percobaan dengan pengujian Marshall sifat-sifat campuran aspal memenuhi kriteria Lapis Aspal Beton Permukaan.
\end{abstract}

Kata kunci-Asbuton, Laston, sifat campuran.

\begin{abstract}
The objective of this research was to use mineral in asbuton as filler and asphalt will be taken into account to reduce the use of oil asphalt in Asphalt Concrete Wearing Course. The material used in this research was aggregate crushed stone from Katunun Mountain, Tanah Laut Regency, South Kalimantan, asphalt Pen 60/70 production of Pertamina and Asbuton grade 15/20. Use of Asbuton 7\% in Asphalt Concrete Wearing Course mixture with optimum asphalt content of 5.25\% mixed properties of VIM 3.5\%, VMA 15.7\%, VFB 77,9\%, Stability $1484 \mathrm{~kg}, \quad$ Flow $3.3 \mathrm{~mm}$, VIM PRD 3.0\%, Stability remaining 90.8\% obtained. At the optimum asphalt content of 5.25\%, mixed experiments with Asbuton grains were varied, 5.0\%, 9.0\%, 11.0\% and 13.0\%. The Marshall test showed that the greater the addition of Asbuton, the higher the stability value, the sequential stability value of $1058 \mathrm{~kg}, 1449 \mathrm{~kg}, 1509 \mathrm{~kg}$ and $1600 \mathrm{~kg}$. Flow range from $3.1 \mathrm{~mm}$ to $3.5 \mathrm{~mm}$. The VIM $3.5 \% \mathrm{up}$ to $5.6 \%, V M A 15.75 \%$ up to $16.87 \%$, VFB $68.1 \%$ up to $71.9 \%$. The experimental results with Marshall testing of the asphalt mixture qualities meet the Asphalt Concrete Wearing Course criteria.
\end{abstract}

Keywords - Asbuton, Asphalt Concrete Wearing Course, Asphalt Mixture Properties

\section{PENDAHULUAN}

A. Latar Belakang

Aspal batu Buton (Asbuton) adalah aspal alam dari Pulau Buton, Propinsi Sulawesi Tenggara. Cadangan aspal alam diperkirakan 300 juta ton. Asbuton terdiri dari mineral antara $75 \%$ sampai dengan $85 \%$ sedang kandungan aspal (bitumen)
$15 \%$ sampai dengan 25\%. Mineral asbuton akan digunakan sebagai bahan pengisi (filler) ukuran butir lolos saringan no. $200(0,075 \mathrm{~mm})$. Kandungan aspal diperhitungkan untuk mengurangi penggunaan aspal minyak. Pada produksi batu pecah dengan mesin pemecah batu (stone crusher) butir lolos saringan no. 200 belum terpenuhi, sehingga untuk memenuhi digunakan mineral dari 
asbuton. Aspal minyak produksi Pertamina belum dapat memenuhi kebutuhan aspal untuk perwatan dan pembangunan jalan baru, sehingga harus import aspal dengan adanya penggunaan asbuton import aspal dapat dikurangi.

\section{B. Maksud dan Tujuan}

Penelitian penggunaan asbuton dalam campuran aspal Laston Permukaan untuk menentukan kadar asbuton yang dinyatakan persen terhadap penggunaan aspal minyak, yang masih memenuhi ketentuan sifat-sifat campuran aspal sesuai spesifikasi umum. Mengetahui pengaruh mineral asbuton sebagai filler terhadap sifat-sifat fisik campuran dan stabilitas. Menentukan kadar aspal optimum dalam campuran aspal.

Penggunaan asbuton untuk mengurangi pemakaian aspal minyak, dikarenakan aspal minyak persedaan terbatas harganya lebih mahal. Pemanfaatan sumber daya alam berupa asbuton sebagai material perkerasan jalan yang lebih murah.

\section{Tinjauan Pustaka}

Lapis aspal beton (Laston) permukaan adalah lapis perkerasan teratas dari struktur perkerasan lentur jalan raya. Laston terdiri campuran dari agregat dengan gradasi menerus adalah gabungan agregat kasar, agregat halus, bahan pengisi (filler) dan bahan aspal keras. Pengerjaan yaitu pencampuran pada unit pencampur aspal (Asphal Mixing Plant/AMP) pada suhu $150^{\circ} \mathrm{C}$, diangkut kelokasi proyek dihamparkan dan dipadatkan.

1) Agregat Kasar: Batu pecah hasil pemecah batu (stone crusher) ukuran butir lolos saringan 19 $\mathrm{mm}$, tertahan saringan no.8 $(2,36 \mathrm{~mm})$. Bentuk partikel agregat yang bersudut memberikan ikatan antara agregat (aggregate interlocking) yang lebih baik yang dapat menahan perpindahan (displacement) agregat yang mungkin terjadi. Keausan maksimum 30\%, Kekerasan (toughness) adalah agregat harus kuat, mampu menahan abrasi dan degradasi selama proses produksi dan operasionalnya di lapangan.

2) Agregat Halus: Batu pecah hasil pemecah batu ukuran butir lolos saringa no.8 (2,36 mm), nilai setara pasir (sand equivalent) minimum 60\%, gumpalan lempung maksimum $1 \%$.

3) Bahan Pengisi (Filler): Bahan lolos saringan no. $200(0,075 \mathrm{~mm})$ bersifat non plastis.

4) Asbuton: Aspal batu Buton merupakan kekayaan sumber daya alam dari pulau Buton. Daerah endapan di Kabungka perkiraan deposit 60 juta ton, kadar bitumen 15\% sampai dengan 35\%. Di Lawele perkraan100 juta ton, kadar bitumen 15\% sampai dengan 30\% (Modul Pendampingan Teknis Pemanfaatan Asbuton BALITBANG PU dengan Direktorat Jenderal Bina Marga, 2007). Persyaratan asbuton butir seperti pada Tabel 1 .

\begin{tabular}{|c|c|c|c|c|}
\hline Sifat-sifat Asbuton & Metode Pengujian & Tipe $5 / 20$ & Tipe $15 / 20$ & Tipe $15 / 25$ \\
\hline Kadar aspal(bitumen) & SNI $03-3640-19980$ & $18-22$ & $18-22$ & $23-27$ \\
\hline Ukuran Butir & & & & \\
\hline Lolos saringan no. $8(2,36 \mathrm{~mm}) \%$ & SNI 03-1968-1990 & 100 & 100 & 100 \\
\hline $\begin{array}{l}\text { Lolos saringan no. } 16(1,18 \mathrm{~mm}) \% \\
\text { Penetrasi bitumen asbuton pada }\end{array}$ & $\begin{array}{l}\text { SNI 03-1968-1990 } \\
\text { SNI 06-2490-1991 }\end{array}$ & $\frac{\operatorname{Min} .95}{\leq 10}$ & $\frac{\text { Min. } 95}{10-18}$ & $\begin{array}{c}\text { Min.95 } \\
10-18\end{array}$ \\
\hline suhu $25^{\circ} \mathrm{C}, 100 \mathrm{~g}, 5$ detik, $0,1 \mathrm{~mm}$ & & & & \\
\hline Kadar air $\quad \%$ & SNI 06-2490-1991 & Maks. 2 & Maks. 2 & Maks.2 \\
\hline
\end{tabular}

5) Aspal Minyak: Aspal minyak disebut juga bitumen yang digunakan adalah jenis aspal keras Pen 60/70 persyaratan seperti Tabel 2.

Sifat-sif at aspal sebagai bahan pengikat sebagai berikut:

a) Aspal adalah bahan yang thermoplastis, yaitu konsistensi atau viscositas akan berubah sesuai dengan perubahan temperatur atau suhu yang terjadi. Semakin tinggi temperature aspal, maka viscositas aspal semakin rendah lebih encer, temperatur rendah maka viscositas tinggi (lebih kental). Pada tahap pelaksanan campuran aspal panas bahan aspal dipanaskan pada temperature tertentu, sehingga didapat viscositas untuk pencampuran, penghamparan dan pemadatan untuk memenuhi sifat workability.

b) Adesi dan kohesi aspal yaitu, adesi adalah kemampuan partikel aspal untuk melekat satusama lainnya, dan kohesi adalah kemampuan aspal untuk melekat dan mengikat agregat.

c) Aspal mempunyai sifat thixotropy, yaitu terjadinya penuaan dan pengerasan aspal. Penuaan aspal disebabkan oleh penguapan fraksi minyak ringan yang terkandung dalam aspal dan oksidasi, 
penuaan jangka pendek dan oksidasi yang progresif menyebabkan penuaan jangka panjang kedua proses penuaan ini mengakibat pengerasan aspal, sehingga aspal menjadi getas dan rapuh.

d) Sifat daya tahan aspal (durability) adalah kemampuan mempertahankan sifat asalnya akibat pengaruh cuaca selama masa pelayanan jalan.

\begin{tabular}{|c|c|c|c|}
\hline No & Jenis Pengujian & Metode Pengujian & $\begin{array}{l}\text { Tipe Aspal } \\
\text { Pen.60-70 }\end{array}$ \\
\hline 1 & Penetrasi pada $25^{\circ} \mathrm{C}(0,1 \mathrm{~mm})$ & SNI 06-2456-1991 & $60-70$ \\
\hline 2 & Viskositas $135^{\circ} \mathrm{C}(\mathrm{cSt})$ & SNI 06-6441-2000 & 385 \\
\hline 3 & Titik lembek $\left({ }^{\circ} \mathrm{C}\right)$ & SNI 06-2434-1991 & $\geq 48$ \\
\hline 4 & Indek Penetrasi & - & $\geq-1,0$ \\
\hline 5 & Daktilitas pada $25^{\circ} \mathrm{C},(\mathrm{cm})$ & SNI 06-2432-1991 & $\geq 100$ \\
\hline 6 & Titik Nyala $\left({ }^{\circ} \mathrm{C}\right)$ & SNI 06-2433-1991 & $\geq 232$ \\
\hline 7 & Kelarutan dalam Trichioor Ethylen (\%) & AASHTO T44-03 & $\geq 99$ \\
\hline 8 & Berat Jenis $\left(\mathrm{g} / \mathrm{cm}^{3}\right)$ & SNI 06-2441-2011 & $\geq 1,0$ \\
\hline
\end{tabular}

6) Gradasi Agregat Gabungan: Gabungan agregat batu pecah hasil pemecah batu (stone crusher) untuk Laston permukaan (Asphalt Concrete Wearing Course/AC-WC) dengan gradasi menerus adalah gabungan agregat kasar, agregat halus, bahan pengisi (filler) dinyatakan dalam persen lolos seperti Tabel 3.

Tabel 3. Gradasi Agregat Gabungan untuk Laston (Asphalt Concrete)

\begin{tabular}{|c|c|c|c|c|}
\hline \multirow{2}{*}{$\begin{array}{c}\text { Nomor } \\
\text { Saringan }\end{array}$} & \multicolumn{3}{|c|}{$\begin{array}{c}\text { Berat lolos terhadap total agregat } \\
\text { dalam campuran }\end{array}$} \\
\cline { 2 - 5 } & \multicolumn{3}{|c|}{ Lapis } \\
\hline$(\mathrm{mm})$ & (in) & Permukaan & Antara & Pondasi \\
\hline 37,500 & $11 / 2^{\prime \prime}$ & & & 100 \\
\hline 25,000 & $1^{\prime \prime}$ & & 100 & $90-100$ \\
\hline 19,100 & $3 / 4^{\prime \prime}$ & 100 & $90-100$ & $73-90$ \\
\hline 12,700 & $1 / 2^{\prime \prime}$ & $90-100$ & $74-90$ & $61-79$ \\
\hline 9,520 & $3 / 8^{\prime \prime}$ & $72-90$ & $64-82$ & $47-67$ \\
\hline 4,760 & No. 4 & $54-69$ & $47-64$ & $39,5-50$ \\
\hline 2,380 & No. 8 & $39,1-53$ & $34,6-49$ & $30,8-37$ \\
\hline 1,190 & No. 16 & $31,6-40$ & $28,3-38$ & $24,1-28$ \\
\hline 0,590 & No. 30 & $23,1-30$ & $20,7-28$ & $17,6-22$ \\
\hline 0,279 & No. 50 & $15,5-22$ & $13,7-20$ & $11,4-16$ \\
\hline 0,149 & No. 100 & $9-15$ & $4-13$ & $4-10$ \\
\hline 0,075 & No. 200 & $4-10$ & $4-8$ & $3-6$ \\
\hline
\end{tabular}

(Sumber: Spesikasi Umum Revisi 3, Departemen Pekerjaan Umum, Direktorat Jenderal Bina Marga, 2010)

7) Karakteristik

Campuran

Aspal: Karakteristik campuran aspal sesuai dengan ketentuan spesifikasi umum. Menurut Silvia Sukirman tahun 2003, karakteristik campuran aspal diuraikan sebagai berikut:

a) Stabilitas adalah kemampuan perkerasan jalan menerima beban lalu lintas tanpa terjadi perubahan bentuk tetap seperti gelombang, alur dan bleeding.

b) Keawetan atau durabilitas adalah kemampuan beton aspal menerima repetisi beban lalulintas seperti berat kendaraan dan gesekan antara roda kendaraan dan permukaan jalan, serta menahan keausan akibat penaruh cuaca dan iklim, seperti udara, air, atau perubahan temperatur.

c) Kekesatan/tahanan geser adalah kemampuan permukaan beton aspal terutama pada kondisi basah, memberikan gaya gesek pada roda kendaraan sehingga kendaraan tidak tergelincir ataupun slip.

d) Kedap air adalah kemampuan beton aspal untuk tidak dapat ditembus air ataupun udara lapisan beton aspal.

e) Kemudahan pengerjaan(Workability) adalah kemampuan campuran beton aspal untuk mudah dihamparkan dan dipadatkan. Kemudahan pelaksanaan menentukan tingkat effisensi pekerjaan.

Menurut Yamin (2002) lapis aspal beton (Laston, $\mathrm{AC}$ ) adalah suatu lapis permukaan yang terdiri dari campuran aspal keras dan agregat yang bergradasi menerus, dicampur, dihamparkan dan dipadatkan dalam kondisi panas dan suhu tertentu. Laston bersifat kedap air, mempunyai nilai struktural, awet, kadar aspal berkisar empat persen sampai tujuh persen terhadap berat campuran, dan dapat digunakan untuk lalu lintas ringan, sedang sampai berat. Campuran ini butiran. Ketentuan sifat-sifat campuran Laston seperti Tabel 4.

\begin{tabular}{|c|c|c|c|c|}
\hline \multirow[b]{2}{*}{ Sifat-sifat Campuran } & & \multicolumn{3}{|c|}{ Laston } \\
\hline & & $\begin{array}{c}\text { Lapis } \\
\text { Aus }\end{array}$ & $\begin{array}{l}\text { Lapis } \\
\text { Antara }\end{array}$ & Pondasi \\
\hline \multirow{2}{*}{$\begin{array}{l}\text { Rasio partikel lolos ayakan } 0,0075 \mathrm{~mm} \\
\text { dengan kadar aspal efektif }\end{array}$} & \multirow{3}{*}{ (\%) } & \multicolumn{3}{|c|}{$\geq 1,0$} \\
\hline & & \multicolumn{3}{|c|}{$\leq 1,2$} \\
\hline Jumlah tumbukan perbidang & & \multicolumn{2}{|c|}{75} & 112 \\
\hline \multirow{2}{*}{ Rongga dalam campuran (VIM) } & \multirow{2}{*}{$(\%)$} & \multirow{2}{*}{\multicolumn{3}{|c|}{$\begin{array}{l}\geq 3,0 \\
\leq 5,0\end{array}$}} \\
\hline & & & & \\
\hline Rongga dalam mineral agregat (VMA) & $(\%)$ & $\geq 15$ & $\geq 14$ & $\geq 13$ \\
\hline Rongga terisi aspal (VFB) & $(\%)$ & $\geq 65$ & $\geq 65$ & $\geq 65$ \\
\hline Stabilitas Marshall & $(\mathrm{kg})$ & \multicolumn{2}{|c|}{$\geq 800$} & $\geq 1800$ \\
\hline \multirow{2}{*}{ Kelelehan Plastis } & \multirow{2}{*}{$(\mathrm{mm})$} & & & $\geq 3,0$ \\
\hline & & & & $\leq 6,0$ \\
\hline $\begin{array}{l}\text { Stabilitas Marshall Sisa setelah perendaman } \\
\text { selama } 24 \mathrm{jam}, 60^{\circ} \mathrm{C}\end{array}$ & $(\%)$ & \multicolumn{3}{|c|}{$\geq 90$} \\
\hline $\begin{array}{l}\text { Rongga dalam campuran pada kepadatan } \\
\text { membal (refusal) }\end{array}$ & $(\%)$ & \multicolumn{3}{|c|}{$\geq 2,0$} \\
\hline
\end{tabular}




\section{METODE PENELITIAN}

Pelaksanaan penelitian di Laboratorium Uji Bahan Politeknik Negeri Banjarmasin, bulan Maret 2017.

Rujukan pengujian bahan-bahan campuran berdasarkan Standar Nasional Indonesia (SNI). Pengujian bahan campuran Lapis Aspal Beton Permukaan meliputi:

1) Pengujian Agregat Kasar: Agregat kasar yang digunakan adalah batu pecah dari mesin pemecah batu (stone crusher) ditambang dari Gunung Katunun. Ukuran butir tertahan saringan 2,36 mm (No.8). Pengujian sifat-sifat fisik dari batuan sebagai agregat kasar dan hubungannya dengan kinerja campuran aspal adalah sebagai berikut:

a) Analisis saringan (SNI 03-1968-1990),

b) Berat jenis dan penyerapan air agregat kasar (SNI 1969 : 2008),

c) Abrasi dengan mesin Los Angeles (SNI 2417 : 2008)

2) Pengujian Agregat Halus: Agregat halus yang digunakan adalah batu pecah dari mesin pemecah batu (stone crusher). Ukuran butir lolos saringan 2,36 $\mathrm{mm}$ (No.8) dan pasir sungai. Pengujian agregat halus sifat fisik agregat adalah sebagai berikut:

a) Analisis saringan (SNI 03-1968-1990),

b) Berat jenis dan penyerapan air agregat halus (SNI 1970 : 2008).

3) Asbuton Butir: Bahan asbuton butir terdiri dari mineral untuk bahan pengisi (filler) dan bitumen atau aspal.Pengujian asbuton butir sebagai berikut:

a) Pengujian kadar bitumen (SNI 03-36401994)

b) Pengujian kadar air (SNI 2490-2008)

c) Pengujian analisa saringan mineral asbuton (SNI 03-1968-1990)

d) Pengujian berat jenis mineral asbuton (SNI 06-2432-1991)

4) Pengujian Aspal Minyak: Aspal minyak yang digunakan sebagai bahan pengikat campran adalah jenis aspal keras pengujian sebagai berikut:

a) Berat jenis aspal keras (SNI 06-2441-1991), b) Penetrasi bahan-bahan bitumen (SNI 062456-1991),

c) Titik lembek aspal dan ter (SNI 06-24341991),

d) Daktilitas pada temperatur $25^{\circ} \mathrm{C}$ (SNI 062432-1991).

5) Pengujian Campuran Aspal Tahap1: Pengujian sifat- sifat campuran pada tahap satu untuk menentukan kadar aspal optimum dengan penambahan asbuton butir sebanyak 7\% terhadap total agregat. Tahapan pelaksanaan penggabungan agregat untuk menentukan proporsi agregat sehingga didapat gradasi yang memenuhi syarat. Pembuatan benda uji dengan kadar aspal yang bervariasi dengan perbedaan $0,5 \%$. Pengujian Marshall berdasarkan RSNI M-01-2003, dari pengujian Marshall didapat kepadatan, rongga dalam campura (VIM), rongga diantara mineral agregat(VMA), rongga terisi aspal (VFB), stabilitas dan kelelehan plastis, kemudian ditentukan kadar aspal yang menghasilkan sifat-sifat campuran yang memenuhi kriteria campuran aspal, kadar aspal ini disebut kadar aspal optimum.Pada kadar aspal optimum dilanjutkan dengan perndaman selama 4x24 jam sehingga diperoleh stabilitas marshall sisa dinyatakan dalam persen. Selanjutnya pengujian persen kepadatan refusal (PRD) disebut juga kepadatan mutlak.

6) Pengujian Campuran Aspal Tahap 2: Pengujian campuran aspal pada kadar aspal optimum dengan variasi penambahan kadar asbuton butir, yaitu 5\%, 9\%, 11\% dan 13\%. Pengujian untuk mengetahui penambahan asbuton butir terhadap sifat-sifat campuran aspal.

\section{HASIL DAN PEMBAHASAN}

Sumber pengambilan agregat untuk bahan campuran aspal dari Gunung Katunun , Pelaihari, Kabupaten Tanah Laut, Provinsi Kalimantan Selatan. Jarak lokasi penambangan batu (quary) Katunun $15 \mathrm{Km}$, dari Jl.Raya Tangkisung Pelaihari dan jarak kota Banjarmasin ke Pelahari adalah 75 $\mathrm{Km}$.

1) Hasil Pengujian Agregat: Bahan agregat dari jenis batu beku dari penambangan batu dan dipecah 
dengan mesin pemecah batu (stone crusher) selanjutnya diperoleh hasil pengujian seperti Tabel 5.

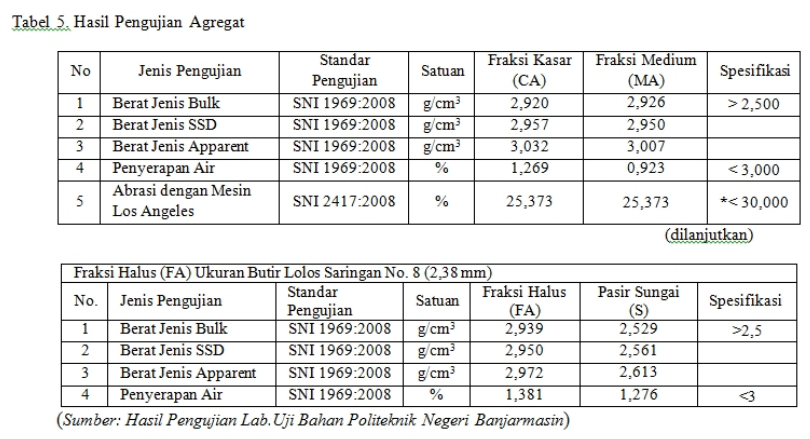

Dari hasil pengujian berat jenis agregat indicator kerapatan massa batuan yang tinggi, dan penyerapan air rendah sehingga didapat keausan rendah adalah menunjukan batuan yang keras dan memenuhi syarat untuk agregat campuran aspal beton alpis permukaan (AC-WC).

2) Hasil Pengujian Asbuton Butir: Material asbuton butir diperoleh dari distributor dan dilakukan pengujian extaraksi untuk menentukan kadar bitumen, analisa saringan mineral hasil extraksi untuk mengetahui gradasinya serta pengujian berat jenis mineral asbuton. Hasil pengujian seperti Tabel 6 .

Tabel 6. Hasil Pengujian Asbuton Butir
\begin{tabular}{|l|l|c|c|c|}
\hline Sifat-sifat Asbuton & Standar Pengujian & Satuan & Hasil Pengujian & Spesifikasi \\
\hline Kadar aspal(bitumen) & SNI 03-3640-19980 & $\%$ & 21,83 & $18-22$ \\
\hline Ukuran Butir & & & & \\
Lolos saringan no.8 $(2,36 \mathrm{~mm})$ & SNI 03-1968-1990 & $\%$ & 100,0 & 100 \\
Lolos saringan no.16 (1,18 mm) & SNI 03-1968-1990 & $\%$ & 100,0 & Min. 95 \\
\hline Berat Jenis & SNI 06-1970-1990 & $\mathrm{g}^{3} \mathrm{~cm}^{3}$ & 1,888 & \\
\hline Kadar air & SNI 06-2490-1991 & $\%$ & 1,47 & Maks.2 \\
\hline
\end{tabular}
(Sumber: Hasil Pengujian Lab.Uji Bahan Politeknik Negeri Banjarmasin)

3) Hasil Pengujian Aspal Minyak: Jenis aspal yang digunakan aspal keras, dengan keterbatasan peralatan Laboratorium maka pengujian aspal hanya sebagian dari yang syaratkan dalam spesifikasi. Hasil pengujian seperti Tabel 7.

Tabel 7 Hasil Pengujian Aspal Minyak

\begin{tabular}{|c|l|c|c|c|c|}
\hline No & \multicolumn{1}{|c|}{ Jenis Pengujian } & Metode Pengujian & Satuan & $\begin{array}{c}\text { Hasil } \\
\text { Pengujian }\end{array}$ & $\begin{array}{c}\text { Spesifikasi } \\
\text { Pen.60-70 }\end{array}$ \\
\hline 1 & Penetrasi pada $25^{\circ} \mathrm{C}$ & SNI 06-2456-1991 & $0,1 \mathrm{~mm}$ & 65,1 & $60-70$ \\
\hline 2 & Viskositas $135^{\circ} \mathrm{C}$ & SNI $06-6441-2000$ & $\mathrm{cSt}$ & & 385 \\
\hline 3 & Titik Lembek & SNI 06-2434-1991 & ${ }^{\circ} \mathrm{C}$ & 40 & $\geq 48$ \\
\hline 4 & Daktilitas pada $25^{\circ} \mathrm{C}$, & \multicolumn{1}{|c|}{ SNI 06-2432-1991 } & $\mathrm{cm}$ & 150 & $\geq 100$ \\
\hline 5 & Berat Jenis & SNI 06-2441-2011 & $\mathrm{g} / \mathrm{cm}^{3}$ & 1,016 & $\geq 1,0$ \\
\hline
\end{tabular}

Hasil pengujian aspal minyak memenuhi syarat aspal keras Pen 60/70.

4) Gradasi Agregat Gabungan: Dari hasil analisa saringan agregat diperoleh gradasi agregat gabungan dengan penambahan asbuton butir 7\% dari berat total agregat, proporsi agregat kasar, medium, halus,pasir sungai dan mineral asbuton seperti Tabel 8.

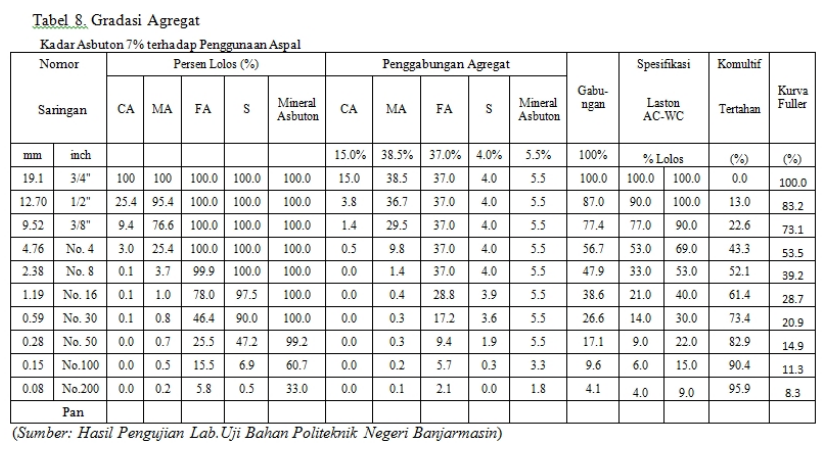

Agregat gabungan dari Tabel 8 maka dapat dinyatakan memenuhi persyaratan spesifikasi gradasi agregat gabungan. Gradasi agregat dibandingkan kurva Fuller dan syarat gradasi dari spesifikasi umum edisi 2010 Revisi seperti Gambar 1, Kurva gradasi agregat gabungan.

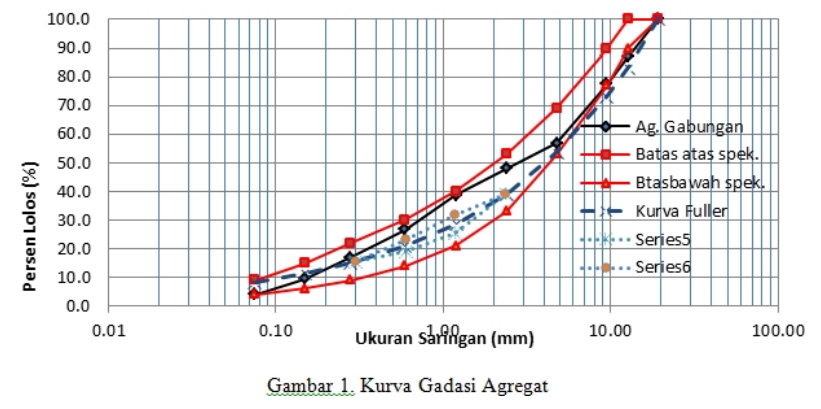

Kurva gradasi agregat gabungan berada diatas kurva Fuller adalah menunjukkan tekstur gradasi agak halus, dan kurva Fuller adalah gradsi yang paling padat.

5) Hasil Pengujian Campuran Aspal: Pengujian campuran aspal dengan alat Marshall tahap 1 untuk 
menentukan kadar aspal optimum dengan agregat. Sifat-sifat campuran aspal seperti pada penambahan asbuton sebanyak $7 \%$ terhadap total

Tabel 9 dan grafik hubungan kadar aspal dengan sifat campuran aspal pada Gambar 2.
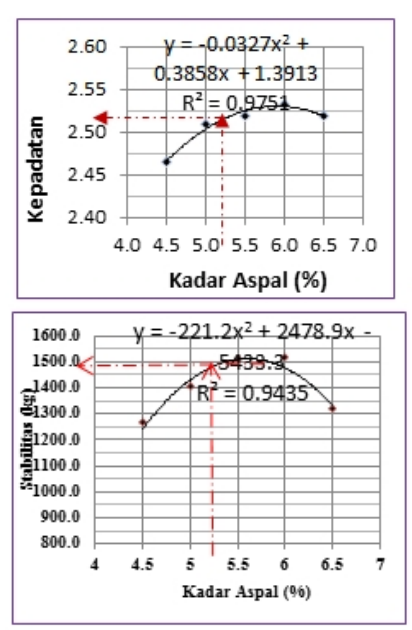
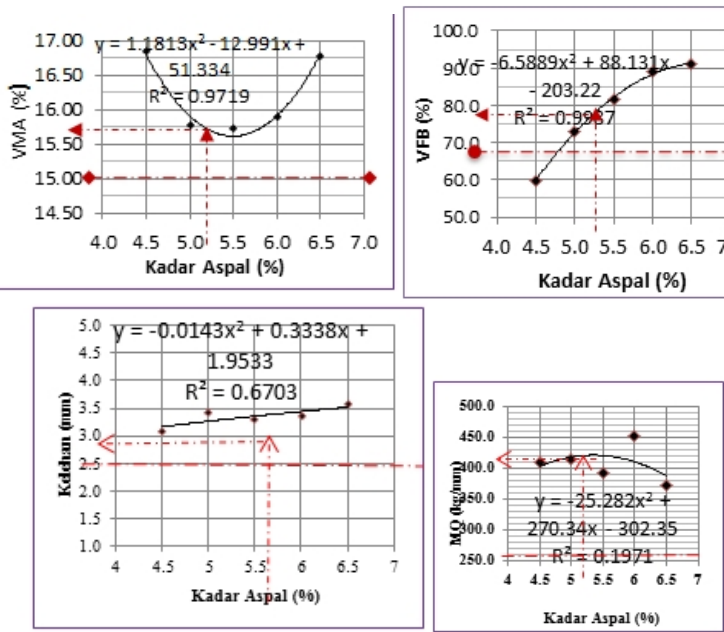
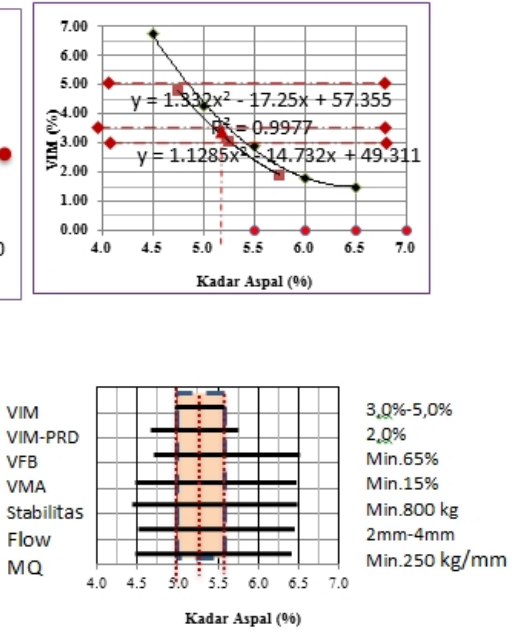

Gambar 2. Grafik Hubungan Kadar Aspal dengan Sifat Campuran

Tabel 9. Hasil Pengujian Marshall

\begin{tabular}{|c|c|c|c|c|c|c|c|c|c|c|c|c|c|c|c|c|c|}
\hline \multirow{3}{*}{$\begin{array}{c}\text { Kadar } \\
\text { Aspal } \\
\text { (\%) }\end{array}$} & \multirow{3}{*}{$\begin{array}{l}\text { BJ Bulk } \\
\text { Total } \\
\text { Agregat } \\
\left(\mathrm{g} / \mathrm{cm}^{2}\right)\end{array}$} & \multirow{3}{*}{$\begin{array}{c}\text { BJ } \\
\text { Efektif } \\
\text { Total } \\
\text { Agregat } \\
\left(\mathrm{g} / \mathrm{cm}^{2}\right)\end{array}$} & \multirow{3}{*}{$\begin{array}{c}\text { BJ } \\
\text { Maks } \\
\text { Campu } \\
\text {-ran } \\
\\
\left(\mathrm{g} / \mathrm{cm}^{3}\right)\end{array}$} & \multicolumn{3}{|c|}{ Berat (gram) } & \multirow{3}{*}{$\begin{array}{l}\text { Isi } \\
\text { benda } \\
\text { uji } \\
\left(\mathrm{cm}^{3}\right)\end{array}$} & \multirow{3}{*}{$\begin{array}{c}\text { Bj Bulk } \\
\text { Campu- } \\
\text { ran } \\
\left(\mathrm{g} / \mathrm{cm}^{3}\right)\end{array}$} & \multirow{3}{*}{$\begin{array}{c}\text { Rongga } \\
\text { Udara } \\
(\%)\end{array}$} & \multicolumn{2}{|c|}{ Stabilitas (kg) } & \multirow{3}{*}{$\begin{array}{c}\text { Kelelehan } \\
\text { Plastis } \\
\text { (Flow) } \\
(\mathrm{mm})\end{array}$} & \multirow{3}{*}{$\begin{array}{c}\begin{array}{c}\text { Hasil } \\
\text { Bagi } \\
\text { Marshall } \\
(\mathrm{kg} / \mathrm{mm}\end{array} \\
\end{array}$} & \multirow{2}{*}{ VMA } & \multirow{2}{*}{ VFB } & \multirow{3}{*}{$\begin{array}{c}\text { Kadar } \\
\text { Aspal } \\
\text { Eff. } \\
(\%)\end{array}$} & \multirow{3}{*}{ 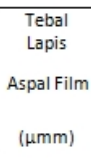 } \\
\hline & & & & Di & Dalam & SSD & & & & $\begin{array}{l}\text { Data } \\
\text { Lab }\end{array}$ & & & & & & & \\
\hline & & & & Udara & Air & & & & & Baca & $\begin{array}{c}\text { Sesuai- } \\
\text { kan }\end{array}$ & & & $(\%)$ & (\%) & & \\
\hline A & $B$ & C & $D$ & $E$ & $\mathrm{~F}$ & G & $\mathrm{H}$ & $\mathrm{J}$ & K & L & M & $\mathrm{N}$ & $P$ & Q & $R$ & u & $v$ \\
\hline \multirow[t]{3}{*}{4.5} & 2.830 & 2.858 & 2.643 & 1120.5 & 668.9 & 1124.5 & 455.6 & 2.459 & 6.930 & 80 & 1149 & 3.10 & 370.65 & 17.00 & 59.23 & \multirow[t]{3}{*}{4.16} & \multirow[t]{3}{*}{6.12} \\
\hline & 2.8298 & 2.858 & & 1127.1 & 672.2 & 1129.2 & 457.0 & 2.466 & 6.669 & 83 & 1192 & 3.30 & 361.24 & 16.77 & 60.23 & & \\
\hline & & & & 1114.8 & 664.5 & 1116.5 & 452.0 & 2.466 & 6.666 & 100 & 1436 & 2.90 & 495.26 & 16.76 & 60.24 & & \\
\hline \multicolumn{8}{|c|}{ Rata-Rata } & 2.464 & 6.755 & & 1259 & 3.10 & 409.05 & 16.84 & 59.90 & \multirow{4}{*}{4.66} & \\
\hline 5.0 & 2.830 & 2.858 & 2.621 & 1117.3 & 675.7 & 1120.8 & 445.1 & 2.510 & 4.211 & 90 & 1293 & 3.80 & 340.16 & 15.73 & 73.23 & & \multirow[t]{3}{*}{6.89} \\
\hline & 2.8298 & 2.858 & & 1119.9 & 676.5 & 1121.9 & 445.4 & 2.514 & 4.053 & 93 & 1336 & 3.20 & 417.41 & 15.59 & 74.00 & & \\
\hline & & & & 1118.3 & 673.3 & 1120.2 & 446.9 & 2.502 & 4.511 & 109 & 1566 & 3.25 & 481.70 & 15.99 & 71.79 & & \\
\hline \multicolumn{8}{|c|}{ Rata-Rata } & 2.509 & 4.258 & & 1398 & 3.42 & 413.09 & 15.77 & 73.01 & & \\
\hline 5.5 & 2.830 & 2.858 & 2.599 & 1122.8 & 681.9 & 1125.9 & 444.0 & 2.529 & 2.699 & 81 & 1163 & 3.10 & 375.28 & 15.55 & 82.65 & \multirow[t]{3}{*}{5.16} & \multirow[t]{3}{*}{7.67} \\
\hline & 2.830 & 2.858 & & 1127.1 & 680.7 & 1128.3 & 447.6 & 2.518 & 3.112 & 105 & 1508 & 3.70 & 407.58 & 15.91 & 80.44 & & \\
\hline & & & & 1130.4 & 681.3 & 1132 & 450.2 & 2.511 & 3.389 & 125 & 1795 & 3.10 & 579.13 & 16.15 & 79.01 & & \\
\hline \multicolumn{8}{|c|}{ Rata-Rata } & 2.519 & 2.905 & & 1489 & 3.30 & 391.431 & 15.730 & 81.543 & & \\
\hline 6.0 & 2.830 & 2.858 & 2.578 & 1122.6 & 684.2 & 1125 & 440.4 & 2.549 & 1.112 & 102 & 1547 & 3.20 & 483.44 & 15.33 & 92.74 & \multirow[t]{3}{*}{5.67} & \multirow[t]{3}{*}{8.46} \\
\hline & 2.830 & 2.858 & & 1136.8 & 685.4 & 1138 & 452.7 & 2.511 & 2.582 & 105 & 1508 & 3.20 & 471.27 & 16.58 & 84.43 & & \\
\hline & & & & 1127.7 & 683.9 & 1129 & 444.8 & 2.535 & 1.646 & 103 & 1479 & 3.70 & 399.82 & 15.78 & 89.57 & & \\
\hline \multicolumn{8}{|c|}{ Rata-Rata } & 2.532 & 1.780 & & 1511 & 3.37 & 451.51 & 15.90 & 88.92 & & \\
\hline 6.5 & 2.830 & 2.858 & 2.557 & 1136.9 & 686.5 & 1139.0 & 452.5 & 2.512 & 1.734 & 86 & 1235 & 3.40 & 363.29 & 16.98 & 89.79 & 6.17 & 9.26 \\
\hline & 2.830 & 2.858 & & 1136.4 & 686.0 & 1137.4 & 451.4 & 2.518 & 1.537 & 85 & 1221 & 3.80 & 321.27 & 16.82 & 90.86 & & \\
\hline & & & & 1138.7 & 688.6 & 1139.5 & 450.9 & 2.525 & 1.229 & 104 & 1494 & 3.50 & 426.77 & 16.56 & 92.58 & & \\
\hline & & Rata-Rat & & & & & & 2.518 & 1.500 & & 1317 & 3.57 & 370.4 & 16.8 & 91.1 & & \\
\hline
\end{tabular}

(Sumber: Hasil Pengujian Lab.Uji Bahan Politeknik Negeri Banjarmasin)

Angka Koreksi Stabilitas
\begin{tabular}{|c|c|c|}
\hline Isi benda uji $\left(\mathrm{cm}^{3}\right)$ & $\begin{array}{c}\text { Tinggi } \\
(\mathrm{mm})\end{array}$ & $\begin{array}{c}\text { Angka } \\
\text { Koreksi }\end{array}$ \\
\hline $444-456$ & 55.6 & 1.25 \\
\hline $457-470$ & 57.2 & 1.19 \\
\hline
\end{tabular}


Hasil pengujian campuran aspal dengan alat Marshall didapat sifat-sifat campuran aspal dari hubungan kadar aspal dengan sifat campuran dipilih kadar aspal yang memenuhi semua persyarat spesikasi untuk Laston permukaan yang disebut kadar aspal optimum. Pada Gambar 9 didapat kadar aspal optimum sebesar 5,25\%.

Bentuk kurva hubungan kadar aspal dengan rongga diantara mineral agregat (VMA) telah memenuhi kriteria pada kondisi cukup ruang pori untuk menampung aspal yang melapisi permukaan agregat dimana titik puncak daerah titik VMA diatas syarat VMA minimum. Kadar aspal optimum sebesar 5,25\% berada sedikit sebelah kiri titik puncak kurva yaitu daerah kering dan dengan rongga terisi aspal 78\% telah memenuhi spesikasi umum, memenuhi kriteria keawetan campuran aspal dari pengaruh oksidasi dan cuaca. Hasil pengujian campuran aspal Laston permukaan dapat diringkas seperti Tabel 10, sebagai berikut.

\begin{tabular}{|c|c|c|c|}
\hline Sifat-sifat Campuran & Satuan & HasilAC-WC & Spesifikasi \\
\hline \multirow{2}{*}{$\begin{array}{l}\text { Rasio partikel lolos ayakan } 0,0075 \mathrm{~mm} \\
\text { dengan kadar aspal efektif }\end{array}$} & \multirow[t]{2}{*}{$\%$} & \multirow{2}{*}{1,21} & Min. 1,0 \\
\hline & & & Maks.1,4 \\
\hline Jumlah tumbukan perbidang & & 75,0 & 75,0 \\
\hline \multirow[b]{2}{*}{ Rongga dalam campuran (VIM) } & \multirow[b]{2}{*}{$\%$} & \multirow[b]{2}{*}{3,5} & Min. 3,0 \\
\hline & & & Maks. 5,0 \\
\hline Rongga dalam mineral agregat (VMA) & $\%$ & 15,7 & 15,0 \\
\hline Rongga terisi aspal (VFB) & $\%$ & 78,0 & 65,0 \\
\hline Stabilitas Marshall & $\mathrm{kg}$ & 1484,0 & 800,0 \\
\hline \multirow{2}{*}{ Kelelehan plastis } & \multirow{2}{*}{$\mathrm{mm}$} & \multirow{2}{*}{3,3} & Min. 2,0 \\
\hline & & & Maks. 4,0 \\
\hline $\begin{array}{l}\text { Stabilitas Marshall Sisa setelah perendaman } \\
\text { selama } 4 \times 24 \text { jam, } 28^{\circ} \mathrm{C}\end{array}$ & $\%$ & 72,8 & 90,0 \\
\hline $\begin{array}{l}\text { Rongga dalam campuran pada kepadatan } \\
\text { membal (refusal) }\end{array}$ & $\%$ & 3,0 & Min. 2,0 \\
\hline
\end{tabular}

6) Pengujian Kepadatan Membal (Refusal): Derajat kepadatan membal disebut juga kepadatan mutlak (percentage refusal density, PRD) adalah rasio antara kepadatan benda uji lapangan terhadap kepadatan refusal dalam satuan persen, yaitu suatu ukuran kepadatan relatife dari suatu contoh campuran beraspal yang dapat digunakan untuk pekerjaan pengendalian mutu. Perencanaan campuran beraspal dengan PRD dilakukan sebagai pendekatan atau simulasi adanya pemadatan lanjutan oleh lalu lintas. Campuran beraspal pada masa pelayanan sesuai umur rencana akan menerima beban lalu lintas secara berulang dengan beban bervariasi dan suhu perkerasan dipengaruhi oleh kondisi cuaca sehingga campuran beraspal sebagai perkerasan jalan kepadatannya bertambah. Hasil pengujian Tabel 11 dan Gambar 3.

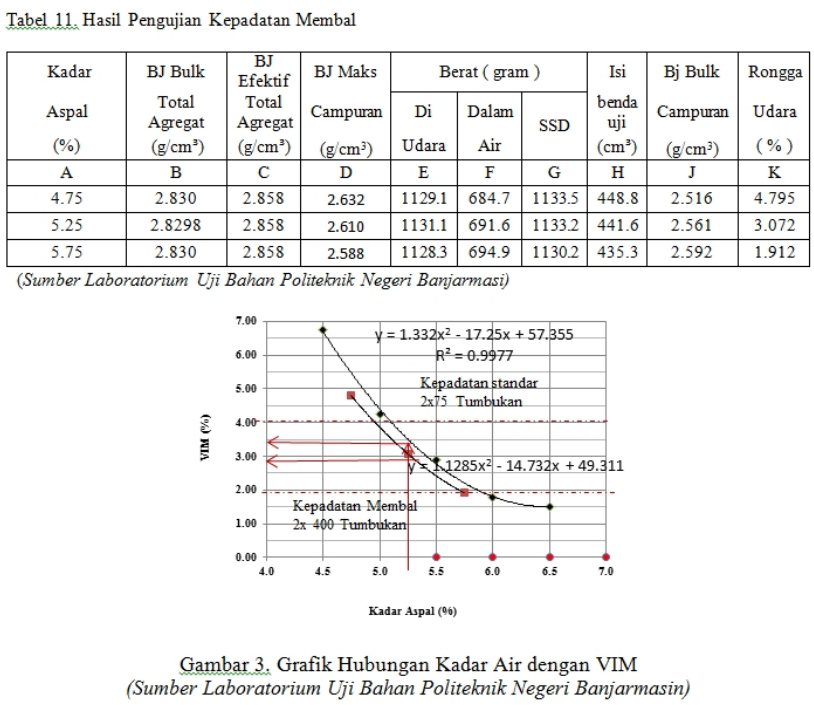

Pengujian kepadatan membal dengan penambahan asbuton butir sebesar 7\% terhadap total agregat pada Tabel 11 dan Gambar 3 dengan kadar aspal optimum 5,25\% rongga dalam campuran standar $3,5 \%$ dan pada kepadatan membal sebesar $3,0 \%$ campuran dalam kondisi stabil dapat mengakomodasi beban berat berulang dan memenuhi spesifikasi umum.

7) Pengujian Stabilitas Marshall dengan Perendaman: Pengujian stabilitas Marshall dengan perendaman pada kadar aspal optimum 5,25\% dan penambahan asbuton butir 7\%, ini dilakukan untuk mendapatkan stabilitas setelah perendaman air selama $4 \times 24$ jam pada suhu ruang $\left(28^{\circ} \mathrm{C}\right)$ dan suhu pengujian $60^{\circ} \mathrm{C}$, untuk mengetahui ketahanan terhadap perendaman air yang dinyatakan dalam persen terhadap stabilitas standar. Hasil pengujian seperti pada Tabel 12.

Tabel 12 . Hasil Pengujian Stabilitas dengan Perendaman Air selama $4 \times 24$ jam pada Suhu Ruang $28^{\circ} \mathrm{C}$

\begin{tabular}{|c|c|c|c|c|c|}
\hline No & $\begin{array}{l}\text { Kadar } \\
\text { Aspal }\end{array}$ & $\begin{array}{l}\text { Stabilitas } \\
\text { Data Lab } \\
\text { Bacaan } \\
\text { Prov. Ring }\end{array}$ & $\begin{array}{l}\text { Stabilitas } \\
\text { sesudah } \\
\text { Perendaman }\end{array}$ & $\begin{array}{l}\text { Stabilitas pada } \\
\text { Kadar Aspal } \\
\text { Optimum }\end{array}$ & $\begin{array}{c}\text { Persen } \\
\text { Stabilitas } \\
\text { Sisa }\end{array}$ \\
\hline & $(\%)$ & & $(\mathrm{kg})$ & (kg) & $(\%)$ \\
\hline 1 & 5.25 & 84 & 1206 & 1484 & 81.3 \\
\hline 2 & 5.25 & 88 & 1264 & 1484 & 85.2 \\
\hline \multirow[t]{2}{*}{3} & 5.25 & 101 & 1451 & 1484 & 97.7 \\
\hline & & & & Rata -rata & 88.1 \\
\hline
\end{tabular}


Hasil stabilitas Marshall dengan perendaman rata-rata $88,1 \%$ lebih kecil dari persyaratan $90 \%$ jadi tidak memenuhi persyaratan spesifikasi umum. Pada perencanaan ini tidak dilakukan penambahan bahan editive aspal yang bersifat anti pengelupasan. Oleh karena itu sesuai dengan spesifikasi umum edisi 2010 revisi Direktur Jenderal Bina Marga harus ditambahkan bahan editive anti penelupasan aspal, agar stabilitas Marshall dengan perendaman meningkat.

8) Gradasi Agregat Gabungan dengan Variasi Penambahan Asbuton Butir: Variasi penambahan asbuton butir untuk mendapat gradasi agregat gabungan yang masih memenuhi persyaratan gradasi sesuai spesifikasi dengan meningkatnya penambahan asubuton butir maka meningkat pula filler pada agregat gabungan serta meningkatkan bitumen dari asbuton sehingga pengurangan terhadap aspal minyak semakin besar. Penambahan asbuton berurutan yaitu 5\%,7\%, 9\%, 11\%, 13\%. Gradasi Agregat gabungan seperti pada Tabel 13.

\begin{tabular}{l} 
Tabel 13. Gradasi Agregat Gabungan dengan Variasi Penambahan Asbuton Butir \\
\begin{tabular}{|c|c|c|c|c|c|c|}
\hline Nomor Saringan & \multicolumn{5}{|c|}{ Gradasi Agregat Gabungan Persen Lolos $(\%)$} \\
\hline mm & inch & $5 \%$ & $7 \%$ & $9 \%$ & $11 \%$ & $13 \%$ \\
\hline 25,4 & $1^{\prime \prime}$ & 100,0 & 100,0 & 100,0 & 100,0 & 100,0 \\
\hline 19,1 & $3 / 4^{\prime \prime}$ & 100,0 & 100,0 & 100,0 & 100,0 & 100,0 \\
\hline 12,70 & $1 / 2^{\prime \prime}$ & 87,1 & 87,0 & 84,3 & 84,9 & 84,9 \\
\hline 9,52 & $3 / 8^{\prime \prime}$ & 77,7 & 77,4 & 74,9 & 75,2 & 75,1 \\
\hline 4,76 & No. 4 & 57,8 & 56,7 & 56,2 & 55,4 & 55,1 \\
\hline 2,38 & No. 8 & 49,2 & 47,9 & 48,3 & 46,9 & 46,6 \\
\hline 1,19 & No. 16 & 39,4 & 38,6 & 39,3 & 38,6 & 38,4 \\
\hline 0,59 & No. 30 & 26,4 & 26,6 & 27,6 & 27,8 & 28,1 \\
\hline 0,28 & No. 50 & 16,2 & 17,1 & 18,3 & 19,1 & 20,0 \\
\hline 0,15 & No.100 & 9,1 & 9,6 & 10,3 & 10,8 & 11,6 \\
\hline 0,08 & No. 200 & 3,7 & 4,1 & 4,5 & 4,9 & 5,31 \\
\hline
\end{tabular} \\
(Sumber Laboratorium Uji Bahan Politeknik Negeri Banjarmasin) \\
\hline
\end{tabular}

9) Pengujian Sifat-sifat Campuran Aspal Dengan Variasi Asbuton Butir: Pengujian dilakukan pada kadar aspal optimum 5,25\% untuk mengetahui pengaruh penambahan asbuton butir pada sifat fisik campuran aspal (Kepadatan, VIM, VMA, VFB) pada gambar 4, dan sifat mekanis (Stabilitas, Kelelehan Plastis) pada Gambar 5.
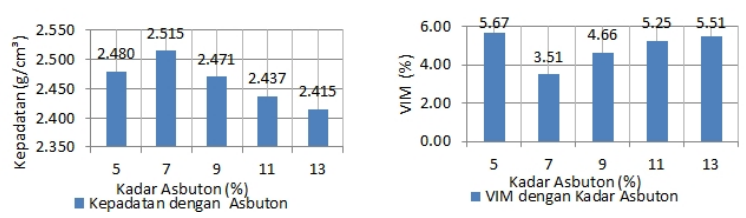
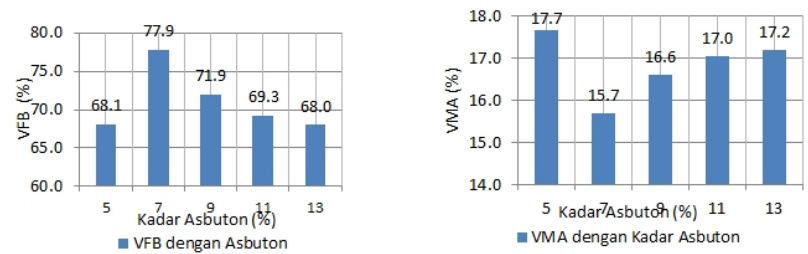

Gambar 4 Sifat-sifat Fisik Campuran Aspal dengan Variasi Asbuton
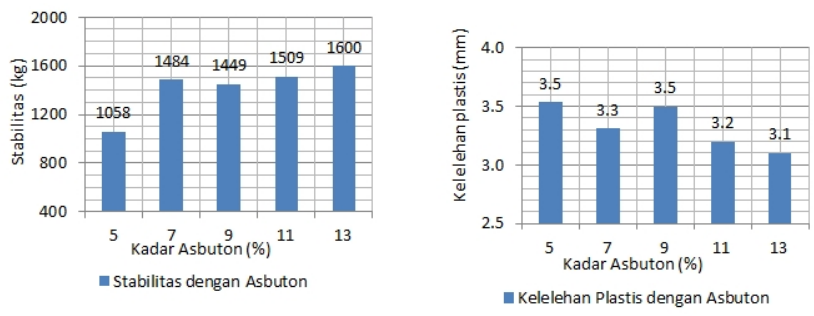

Gambar 5 Sifat-sifat Mekanik Campuran Aspal dengan Variasi Asbuton

(Sumber Laboratorium Uji Bahan Politeknik Negeri Banjarmasin)

Hasil pengujian sifat-sifat campuran aspal dengan penambahan asbuton 7\% diperoleh kepadatan optimum juga sifat-sifat campuran seperti VMA,VFB dan VIM dan stabilitas tertinggi dengan kelelehan plastis sebesar 3,3 mm. Ringkasan hasil pengujian sifat-sifat campuran aspal Laston permukaan dengan variasi penambahan asbuton butir pada Tabel 14.

\begin{tabular}{|c|c|c|c|c|c|c|c|}
\hline \multirow[b]{2}{*}{ Sifat-sifat Campuran } & \multirow{2}{*}{$\begin{array}{l}\text { Satu- } \\
\text { an }\end{array}$} & \multicolumn{5}{|c|}{ Hasil Pengujian } & \multirow{2}{*}{\begin{tabular}{|l|}
$\begin{array}{l}\text { Spesifi- } \\
\text { kasi }\end{array}$ \\
\end{tabular}} \\
\hline & & $5 \%$ & $7 \%$ & $9 \%$ & $11 \%$ & $13 \%$ & \\
\hline \multirow{2}{*}{$\begin{array}{l}\text { Rasio partikel lolos ayakan } 0,075 \mathrm{~mm} \\
\text { dengan kadar aspal efektif } \\
\text { Jumlah tumbukan perbidang }\end{array}$} & \multirow[t]{2}{*}{$\%$} & 1,3 & 1,2 & 1,1 & 1,0 & 0,9 & $\begin{aligned} \text { Min. } 1,0 \\
\text { Maks.1.4 }\end{aligned}$ \\
\hline & & 75 & 75 & 75 & 75 & 75 & 75 \\
\hline \multirow{2}{*}{ Rongga dalam campuran (VIM) } & \multirow[b]{2}{*}{$\%$} & \multirow[b]{2}{*}{4,6} & \multirow[b]{2}{*}{3,5} & \multirow{2}{*}{4,7} & \multirow[b]{2}{*}{4,9} & \multirow[b]{2}{*}{5,2} & Min. 3,0 \\
\hline & & & & & & & Maks. 5,0 \\
\hline Rongga dalam mineral agregat (VMA) & $\%$ & 16,3 & 15,7 & 16,6 & 16,7 & 16,8 & 15,0 \\
\hline Rongga terisi aspal (VFB) & $\%$ & 71,9 & 78,0 & 71,7 & 70,7 & 69,4 & 65,0 \\
\hline Stabilitas Marshall & $\mathrm{kg}$ & 1058,0 & 1484,0 & 1449,0 & 1509,0 & 1600,0 & 800,0 \\
\hline Kelelehan plastis & $\mathrm{mm}$ & 3,5 & 3,3 & 3,5 & 3,2 & 3,1 & $\begin{array}{r}\text { Min.2,0 } \\
\text { Maks } 4,0\end{array}$ \\
\hline $\begin{array}{l}\text { Stabilitas } \\
\text { perendaman selama } 4 \times 24 \text { jam, } 22^{\circ} 8^{\circ} \mathrm{C}\end{array}$ & $\%$ & & 88,1 & & & & 90,0 \\
\hline $\begin{array}{l}\text { Rongga dalam campuran pada kepadatan } \\
\text { membal (refusal) }\end{array}$ & $\%$ & & 3,0 & & & & Min. 2,0 \\
\hline Kepadatan & $\mathrm{g} / \mathrm{cm}^{3}$ & 2,480 & 2,515 & 2,471 & 2,437 & 2,415 & \\
\hline
\end{tabular}

\section{KESIMPULAN}

Berdasakan pengujian dan pengolahan data besarnya penambahan asbuton butir 7\%, kadar aspal optimum sebesar 5,25. Klasifikasi asbuton butir 15/20, kadar bitumen 16,63\% sampai dengan $16,87 \%$. Sifat-sifat campuran Rasio butir lolos ayakan $0,075 \mathrm{~mm}$ dengan kadar aspal efektif 1,2; VIM 3,5\%, VMA 15,7\%, VFB 77,9\%, Stabilitas $1484 \mathrm{~kg}$, Kelelehan plastis 3,5 mm, VIM PRD 3,0\%, 
Stabilitas sisa $88,1 \%$ dan Kepadatan $2,515 \mathrm{~g} / \mathrm{cm}^{3}$. Hasil percobaan dengan pengujian Marshall sifatsifat campuran aspal memenuhi kriteria Lapis Aspal Beton Permukaan.

Pada kadar aspal optimum sebesar $5,25 \%$ dilakukan percobaan campuran dengan penambahan Asbuton butir bervariasi 5,0\%, 9,0\%, $11,0 \%, \quad 13,0 \%$ dari hasil pengujian Marshall menunjukan bahwa semakin besar penambahan Asbuton maka semakin tinggi nilai stabilitasnya, nilai stabilitas berurutan sebesar $1058 \mathrm{~kg}, 1449 \mathrm{~kg}$, $1509 \mathrm{~kg}, \quad$ dan $1600 \mathrm{~kg}$. Kelelehan plastis menunjukan kelenturan campuran aspal menurun dari rentang 3,5 $\mathrm{mm}$ sampai dengan $3,1 \mathrm{~mm}$.

\section{REFERENSI}

Departemen Pekerjaan Umum. 1999. Pedoman Penggunaan Aspal Karet dalam Campuran Beraspal Secara Panas, PT. Mediatama Saptakarya, Jakarta.

Departemen Pekerjaan Umum. 1999. Pedoman Perencanaan Campuran Beraspal Panas dengan Kepadatan Mutlak, PT. Mediatama Saptakarya, Jakarta.

Departemen Pekerjaan Umum. 1991. SNI-06-2432-1991 Metode Pengujian Daktilitas Bahan-Bahan Aspal, Pustran.Balit .Bang, Bandung.

Departemen Pekerjaan Umum. 1991. SNI-06-2433-1991 Metode Pengujian Titik Nyala dan Titik Bakar Dengan Alat Cleveland Open Cup, Pustran.Balit.Bang, Bandung.

Departemen Pekerjaan Umum. 1991. SNI-06-2441-1991 Metode Pengujian Berat Jenis Aspal Padat, Pustran.Balit .Bang, Bandung.

Departemen Pekerjaan Umum. 1991. SNI-06-2456-1991 Metode Pengujian Penetrasi Bahan-bahan Bitumen, Pustran.Balit.Bang, Bandung.

Departemen Pekerjaan Umum. 1991. SNI-06-2434-1991 Metode Pengujian Titik Lembek Aspal Dengan Alat Cincin dan Bola (Ring and Boll), Pustran.Balit.Bang, Bandung.

Departemen Pekerjaan Umum. 1990. RSNI-M-01-2003 Metode Pengujian Campuran Beraspal Dengan Alat Marshall, Pustran.Balit.Bang, Bandung.

Departemen Pekerjaan Umum. 1990. SNI-03-1968-1990 Metode Pengujian Tentang Analisa Saringan Agregat Halus dan Kasar, Pustran.Balit.Bang, Bandung.
Departemen Pekerjaan Umum. 1990. SNI-03-1969-1990 Metode Pengujian Berat Jenis dan Penyerapan Air Agregat Kasar, Pustran.Balit.Bang, Bandung.

Departemen Pekerjaan Umum. 1990. SNI-03-1970-1990 Metode Pengujian Berat Jenis dan Penyerapan Air Agregat Halus, Pustran.Balit.Bang, Bandung.

Departemen Pekerjaan Umum. 1991. SNI-03-2417-1991 Metode Pengujian Keausan Agregat dengan Mesin Abrasi Los Angeles, Pustran.Balit.Bang, Bandung.

Departemen Pekerjaan Umum. 1991. SNI-03-2439-1991 Metode Pengujian Kelekatan AgregatTerhadap Aspal, Pustran.Balit.Bang, Bandung.

Departemen Perkerjaan Umum. 1987. SKBI.2.3.26, UDC: 625.73(02) Petunjuk Perencanaan Tebal Perkerasan Lentur dengan Metode Analisa Komponen. Jakarta.

Departemen Pemukiman dan Prasarana Wilayah. 2002. PtT01-2002-B Pedoman Perencanaan Tebal Perkerasan Lentur. Jakarta.

Direktorat Jenderal Bina Marga, Departemen Pekerjaan Umum. 2010. Spesikasi Umum, Jakarta.

Direktorat Jenderal Prasarana Wilayah, Dep.Kim.Pras.Wil. 2002. Manual Pekerjaan Campuran Beraspal Panas, Jakarta.

Direktorat Jenderal Bina Marga, PUSLITBANG Jalan dan Jembatan, 2007, Modul Pendampingan Teknis Asbuton untuk Pemeliharan dan Pembangunan Jalan, Jakarta

Direktorat Jenderal Bina Marga, Departemen Pekerjaan Umum, APBN TA 2007,Spesifikasi Khusus, Jakarta.

Departemen Pekerjaan Umum. 1999. Pedoman Perencanaan Campuran Beraspal Panas dengan Kepadatan Mutlak, PT. Mediatama Saptakarya, Jakarta.

Departemen Pekerjaan Umum. 1991. SNI-06-2432-1991 Metode Pengujian Daktilitas Bahan-Bahan Aspal, Pustran.Balit .Bang, Bandung. 